ARTIGOS

\title{
Construindo idéias sobre a juventude envolvida com a criminalidade violenta
}

\section{Building ideas on youth involved in violent crimes}

\author{
Andréa Máris Campos Guerra* \\ Professora do Programa de Pós-Graduação em Psicologia da Pontifícia Universidade \\ Católica - PUC, Belo Horizonte, MG, Brasil
}

J acqueline de Oliveira Moreira**

Professora do Programa de Pós-Graduação em Psicologia da Pontifícia Universidade Católica - PUC, Belo Horizonte, MG, Brasil

Nádia Laguárdia de Lima***

Professora do Curso de Psicologia da Pontifícia Universidade Católica - PUC, Belo Horizonte, MG, Brasil

Bárbara Drumond da Silveira Pompeo****

Pontifícia Universidade Católica - PUC, Belo Horizonte, MG, Brasil

Camila Alves Noberto Soares*****

Pontifícia Universidade Católica - PUC, Belo Horizonte, MG, Brasil

Liliany Mara Silva Carvalho******

Pontifícia Universidade Católica - PUC, Belo Horizonte, MG, Brasil

Naiane de Andrade Nascimento Pechir*******

Pontifícia Universidade Católica - PUC, Belo Horizonte, MG, Brasil

\begin{abstract}
RESUMO
Revisando a bibliografia atual sobre o tema da violência urbana entre jovens, verificamos que o contexto nacional de convivência com a desigualdade social acirra a violência entre jovens moradores de aglomerados urbanos. Essa violência é potencializada pela experiência da adolescência - transição que marca a perda do corpo e dos pais infantis, bem como o encontro com o outro sexo -, bem como pela experiência errante de desfiliação histórica, que caracteriza a subjetividade na contemporaneidade. Dessa maneira, supomos que, diante da precariedade de significação social da cultura contemporânea, o jovem tenta encontrar novas formas de estabelecer-se no laço social, buscando alguma amarra coletiva pela via do crime. Assim, a entrada numa gangue ou
\end{abstract}


num circuito criminoso pode oferecer, diante dessa carência simbólica, uma promessa de sentido social e uma ilusão afetiva, favorecendo a violência.

Palavras-chave: Juventude, Criminalidade violenta, Pós-modernidade, Adolescência.

\begin{abstract}
Reviewing the current literature on the theme of urban violence among young people, we see that the national context of coexistence with the social inequality increases violence among young people from urban areas. This violence is reinforced by the experience of adolescence - transition that marks the loss of the children's body and children's parents, and the meeting with the other sex - as well as the experience of historical helplessness, which characterizes the subjectivity in contemporaneity. Thus, we suppose that, given the precariousness of social significance of the contemporary culture, the young people tries to find new ways to establish themselves in the social link, seeking some collective ties through the crime. So, the entry into a criminal gang or circuit can offer, face this symbolic grace, a promise to a social sense and an affective illusion, encouraging violence.
\end{abstract}

Keywords: Youth, Violent crime, Post-modernity, Adolescence.

\title{
I ntrodução
}

Inquietante é a observação empírica das escolhas de vida realizadas entre jovens dos aglomerados urbanos. Do mais extremo assujeitamento às formas mais variadas de resistência, seja à pobreza, seja à falta de recursos sociais e simbólicos, deparamo-nos com um quadro que convoca a reflexão. Por que alguns jovens encontram saídas pelo hip-hop, enquanto outros respondem com o envolvimento com o tráfico? Foi-se o tempo em que era possível acreditarmos apenas numa determinação sócio-econômica.

Por outro lado, formular essa questão do ponto de vista causal, da busca pela determinação dessas respostas, não exime a responsabilidade do próprio sujeito pela posição que constrói? Centrar no sujeito o foco da explicação também não resolve o impasse. Estamos diante de uma situação complexa, que extrapola o campo de um saber específico. A História, a Geografia, a Economia, a Arquitetura, a Psicologia, enfim, um conjunto de especialidades se debruçam sobre a complexidade do tema da juventude envolvida com a violência.

Neste artigo, pretendemos levantar algumas hipóteses que possam contribuir com a ampliação da leitura dessa questão. Interrogando o modo como se inscrevem no laço social, perguntamos sobre a relação que os jovens estabelecem com a criminalidade violenta. Como nosso foco é a análise da via de enlaçamento social pela criminalidade, deixamos, para outro momento, a reflexão comparativa sobre saídas por 
vias socialmente mais desejáveis, como, por exemplo, aquelas empreendidas pelo hip-hop.

Para isso, tomaremos em foco o cenário nacional, brasileiro, buscando nele localizar pontos de articulação do envolvimento de jovens com a criminalidade violenta. Realizamos extensa revisão bibliográfica, buscando o ponto visado em nossa análise, qual seja, a relação entre a juventude de aglomerados urbanos e a criminalidade violenta, entendendo jovens as pessoas entre 14 e 24 anos. Em seguida, desenvolveremos duas vias de argumentação: uma primeira referente à discussão do contexto pós-moderno e seus desdobramentos junto aos modos de subjetivação contemporâneos, e outra referente ao momento da adolescência, passagem necessária e determinante na vida de qualquer sujeito. A escolha por essas vias visa promover um diálogo possível entre ao menos dois aspectos articuladores da relação entre juventude e criminalidade violenta. Vamos a elas.

\section{O cenário nacional}

No contexto sócio-político e cultural contemporâneo, a multiplicidade de formas sociais e subjetivas de resposta ao capitalismo avançado e globalizado ganha contornos que exigem, muitas vezes, a intervenção do Estado. Os processos de subjetivação contemporâneos (BAUMAN, 2004; BIRMAN, 1999) são marcados pelo hedonismo, pelo imediatismo, pelo consumismo exacerbado e pela liquidez na articulação do laço social. Essas respostas, ainda que pareçam configurar uma universalidade independente dos contextos nacionais e locais, ganham especificidades únicas se observadas e analisadas em sua particularidade.

Em especial em nosso país, no qual a linha da miséria é hoje de 19,3\%, atingindo cerca de 36,2 milhões de pessoas, segundo dados colhidos no site da Fundação Getúlio Vargas ${ }^{1}$ os estilos de sobrevivência e resposta neste cenário são muito díspares, conforme as regiões geográficas e os contextos culturais nos quais se desenvolvem. Considera-se linha de miséria a faixa social que sobrevive com renda de até $R \$ 125,00$ por mês. A pesquisa intitulada Mapa do Fim da Fome, coordenada pelo economista Macelo Néri, que nos traz esses índices, se baseia em dados da Pesquisa Nacional por Amostra de Domicílios (Pnads) e da Pesquisa Mensal de Empregos (PME) do Instituto Brasileiro de Geografia e Estatísticas (IBGE).

Em 1993, antes do Plano Real, a miséria atingia 35,16\% dos brasileiros. Em 1995, o percentual recuou para $28,79 \%$ da população e neste patamar ficou até 1997. Em 1998, o número de pobres voltou a diminuir, mas subiu nos anos seguintes e 
encerrou a era FHC com alcance de $26,72 \%$. No primeiro ano de Lula, a pobreza refletiu a crise econômica e cresceu para $28,17 \%$ dos brasileiros. Desde então, o total de pobres só faz recuar. Em 2004, para 25,38\%, seguido de $22,77 \%$ da população em 2005. Em 2006, 7 milhões de pessoas saíram da linha da miséria. Foi uma queda expressiva de 15\%, mas cerca de 36,2 milhões de pessoas (o equivalente a $19,3 \%$ da população) ainda recebem menos de $\mathrm{R} \$ 125$ por mês (J ornal do Brasil, 19/09/2007).

Se, de 2003 a 2006, a queda foi de 33\% neste índice, em função sobretudo de políticas compensatórias como a Bolsa-Família, fato é que grande parcela da população ainda se debate com a sobrevivência no Brasil. Os estados da região norte e nordeste são os que mais sofrem com a pobreza. O estado de Minas Gerais teve em 2001 uma taxa de indigência de $26,79 \%$, sendo o décimo quinto estado do país com uma situação precária, apesar do crescente investimento na superação da desigual distribuição de riquezas.

Curiosamente, a elevação do nível de miséria e o processo de redemocratização no país, que deveriam sinalizar para um quadro de melhoria da qualidade de vida da população, vieram acompanhados do aumento crescente da taxa de criminalidade e, mais especialmente, de homicídios entre homens jovens (ZALUAR, 1985; ZALUAR, 2007). Tradicionalmente essa criminalidade vem associada a duas interpretações. Ora ela é pensada como determinada por fatores econômicos (PARKER; SMITH, 1979; TAYLOR et al., 1980 apud BEATO, 1998). E, neste caso, falta de oportunidades, desigualdade social e marginalização seriam tomados como estímulos decisivos para uma resposta criminosa no laço social. Ora é pensada como agressão às normas de boa convivência, ao consenso moral e normativo da sociedade (DURKHEIM, 1978; SHERMAN; BERK, 1984; CLARKE, 1983; KRAUT, 1976 apud BEATO, 1998). E, nesse sentido, estaria centrada numa tomada de posição que partiria essencialmente do sujeito.

A esses estudos clássicos temos que somar a idiossincrasia do contexto brasileiro, no qual as versões acerca da incidência da criminalidade violenta vêm associadas à organização do tráfico e a ineficácia de intervenção do Estado. O dossiê sobre o crime organizado, apresentado por Zaluar (2007), articula esse aumento crescente ao cruzamento de quatro dimensões: o contexto internacional do tráfico de drogas e de armas de fogo; a importância e os limites das explicações macrossociais sobre a criminalidade violenta que interage com os mecanismos transnacionais do crime organizado; a inércia institucional que explica a ineficácia do sistema de justiça; os processos microssociais ou as 
formações subjetivas sobre a concepção de masculinidade em suas relações com a exibição de força, dinheiro e armas de fogo.

Outras pesquisas recentes, voltadas ao contexto brasileiro, evidenciam essas tendências, destacando algumas particularidades locais e nacionais (ASSIS; SOUZA, 1999; CHESNAIS, 1999; JUNQUEIRA; JACOBY, 2006; NUNES, 2005; SANT'ANNA; AERTS; LOPES, 2005; SILVA, 2004). Essencialmente as pesquisas apontam para o estado de vulnerabilidade social, econômica e afetiva, somado à influência do uso de drogas e círculo de amigos como determinantes para uma posição dos jovens, em contato com atos violentos, inserirem-se no laço social pela ação criminosa. Assim, o clássico estudioso do tema, Chesnais (1999) apresenta um amplo diagnóstico da violência no Brasil ressaltando como fatores que possibilitam o crescimento da violência criminal no país, ou seja, fatores sócio-econômicos, conjunturais e estruturais, a fraqueza e descrédito das instituições e a carência do Estado para administrar a repressão e propiciar a prevenção. Junqueira e Jacoby (2006) atribuem ao uso de drogas, à vida na comunidade, ao grupo de amigos, à relação com o trabalho, à família e à escola os elementos contributivos para a execução de delitos. A pesquisa de Sant'Anna et al (2005), realizada no Sul do país, traz como resultados que os jovens envolvidos com a criminalidade encontravam-se em situação de vulnerabilidade social, indicada pelo alto abandono $(78,9 \%)$ escolar e a baixa renda per capita e escolaridade dos pais. Apresentavam também situações de vulnerabilidade relacionadas ao gênero, com predomínio de mortes entre o sexo masculino $(91,2 \%)$, e ao comportamento, sendo que $40,4 \%$ consumiam bebidas alcoólicas, $45,6 \%$ drogas ilícitas e 58,6\% apresentavam história de antecedentes criminais.

Em todas essas pesquisas, a indicação para a ação em termos de políticas públicas centra-se no incremento e fortalecimento da rede social comunitária e da intervenção do Estado, sobretudo nos setores da Saúde e da Educação, além da expectativa de intervenção em termos de redistribuição de renda e segurança pública, trazendo credibilidade ao Estado. Também afirmam a importância do investimento em ações sociais e intersetoriais, principalmente relacionadas à convivência familiar, comunitária e à escola, como uma resposta às vulnerabilidades programáticas, sociais e individuais às quais o jovem encontra-se exposto (JUNQUEIRA; JACOBY, 2006; SANT'ANNA; AERTS; LOPES, 2005). Na mesma linha, Chesnais (1999) traz como recomendações políticas, baseadas na observação da evolução de outros países, o restabelecimento da credibilidade do Estado, a partir da redistribuição da renda; do investimento nas áreas sociais, sobretudo de saúde e 
educação; e da reestruturação de suas instituições fundamentais, como a polícia e a escola.

Beato (1998) aposta numa estratégia de intervenção e combate à criminalidade violenta orientada pela distribuição espacial das ações criminosas. Entram na categoria de criminalidade violenta o homicídio, a tentativa de homicídio, o estupro, o roubo e o roubo à mão armada, distribuídos em taxas por cem mil habitantes. Para ele, é necessário um deslocamento da leitura do criminoso para uma sociologia do crime que parta de sua distribuição espacial. Assim, em sua pesquisa sobre os determinantes da criminalidade em Minas Gerais, ele considera quatro aspectos preliminares:

A) Deslocamento da análise do criminoso para a análise do delito, o que reforça as teorias da oportunidade dos crimes e demonstração dos comportamentos racionais para atividade criminosa.

B) Não tratamento do "crime" de uma forma geral, mas das condições de incidência de determinados tipos de crime.

C) Não interesse pela causalidade, substituída por uma orientação próativa de detectar padrões espaciais e temporais de determinados tipos de delitos a fim de poder antecipar a ocorrência dos eventos.

D) Implementação de políticas públicas preventivas de combate à criminalidade, que requerem a identificação das comunidades e locais que serão objeto da ação assistencialista e preventiva.

Sua abordagem, portanto, é orientada: (a) pela mudança de enfoque dos criminosos para os correlatos espaciais da ocorrência dos delitos; e (b) pelo tratamento em separado das variáveis que compõem a criminalidade violenta. Dessa maneira, ele espera tratar os municípios a partir de suas características estruturais em relação à incidência de determinados tipos de crimes.

Alguns dos resultados a que ele chega nos interessam diretamente e, por isso, os reunimos abaixo.

(1) Os delitos criminais são fenômenos bastante concentrados espacial e temporalmente.

(2) Ao contrário do que verificamos nas pesquisas e estudos sobre a criminalidade, a correlação a ser estabelecida para a explicação do crime não é com a pobreza, mas com a riqueza.

(3) Ao grau de desenvolvimento de uma região corresponderá uma pauta de delitos consistente com as referências de ordem cultural ordenadoras das estruturas de preferências que orientam a ação criminosa.

(4) E, assim, confirma o modelo de que delitos são dependentes de oportunidades para contato social (GLAESER, 1996 apud BEATO, 1998). 
(5) O aumento da criminalidade é a contraface do desenvolvimento, devido ao aumento das oportunidades para o crime. Este incremento corresponde também ao decréscimo da vigilância por parte dos grupos primários e ao seu anonimato.

Em sua dissertação de mestrado, Nascimento (2004) analisou os fatores sociais envolvidos, direta ou indiretamente, nas altas taxas de violência e criminalidade em vilas e favelas dos grandes centros urbanos, tomando a região metropolitana de Belo Horizonte em análise. Nestes locais, nos quais as comunidades são assoladas por gangues juvenis, tráfico de drogas e outros crimes, Nascimento buscou identificar e analisar os fatores que propiciam as altas taxas de criminalidade. Ele parte do pressuposto de que essa incidência da criminalidade é conseqüência direta ou indireta da forma de articulação de fatores históricos, geográficos, culturais, econômicos e estruturais. Donde a importância de se compreender a trama discursiva que compõe o cenário no qual os laços sociais e comunitários se articulam.

Numa linha de trabalho que buscou interrogar a articulação social do jovem, ligado direta ou indiretamente à criminalidade violenta, Diógenes (1998) realizou sua pesquisa de doutorado, buscando extrair a cartografia do envolvimento desses adolescentes com a violência urbana em Fortaleza. Discute a marca de rebeldia da juventude, os estilos e os rituais de suas formas de relação (gangue e galera), sua inscrição no território e suas formas de expressão (hip hop e violência armada), o corpo, a gíria e a relação com a polícia. Fortalece, assim, no Brasil, uma leitura deste fenômeno da violência urbana praticada por adolescentes descolada da tradiconal articulação tráfico-armas de fogo-crimes violentos, posto que voltada à descrição e análise do estilo de resposta desses jovens e suas razões discursivas, extraídas do próprio texto e contexto de suas vidas.

Assim como de um lado, Beato (1998) desloca do criminoso para o crime em sua configuração territorial a análise do fenômeno da criminalidade violenta; Diógenes (1998) desloca o estigma do criminoso para a pergunta sobre o sujeito no cenário social em suas diferentes maneiras de reagir aos impasses contemporâneos que o atormentam. Com seu livro, verificamos menos a proeminência do bandido que a presença do sujeito em suas articulações discursivas no laço social. Numa linha aproximada, também o livro de MVBill, Celso Athayde e Luiz Eduardo Soares, Cabeça de Porco (2005), inova, buscando retratar a realidade dos jovens envolvidos com o tráfico em sua humanidade mais radical e destituída de preconceito. Eles se interrogam pela escolha pela vida do crime e seguem o caminho clássico que articula a violência urbana dos jovens de aglomerados ao narcotráfico, sem, entretanto, 
buscar aprofundar a investigação com análises sociológicas ou psicológicas para o fenômeno. Eles falam e deixam falar seus sujeitos num tom mais jornalístico e de auto-depoimento que propriamente reflexivo e científico.

Sabemos que, na contemporaneidade, os laços sociais e afetivos são tênues em função de uma mudança estrutural em termos econômico, cultural, social e de costumes de grande monta. E, por outro lado, sabemos que o período de vida que esses jovens atravessam, em si mesmo, - o da adolescência - diz respeito a uma lógica marcada por profundas ressignificações simbólicas que favorecem rupturas e crises. É impossível avançar na discussão do estilo de entrada e manutenção destes jovens no laço social, em especial na discussão pela escolha pela criminalidade violenta, prescindindo da análise desses dois importantes fatores, macro-estrutural e micro-subjetivo.

Dessa forma, a fim de levar adiante nossa discussão, tomaremos em foco esses dois aspectos - a sociedade contemporânea e a adolescência - de forma a munirmo-nos de arsenal reflexivo para a análise do laço social, voltado à criminalidade violenta, estabelecido pelos jovens moradores de aglomerados urbanos.

\section{Um panorama mais amplo: a pós-modernidade}

A consciência da autonomia subjetiva, da liberdade individual e o senso de privacidade, talvez seja uma das maiores inovações da sociedade moderna em relação à era clássica. As sociedades clássicas possuíam uma forma holista e hierárquica de organização, na qual a identidade do indivíduo era vivida na e para a vinculação social. As sociedades modernas baseiam-se no individualismo, o sujeito sente-se livre e autônomo, mas perde a forma simbólica de proteção contra o desamparo oferecida pela sociedade holista (DUMONT, 1985). O sujeito moderno está sozinho, entregue a sua própria sorte. A forma simbólica moderna de proteção contra a situação de desamparo, reatualizada com a descoberta do espaço infinito, é a racionalidade. Essa perspectiva é inaugurada com a frase cartesiana: "penso, logo existo". Nesse ponto não podemos deixar de comparar a vivência da juventude em uma sociedade holista em relação a uma individualista. A organização social holista estabelece ritos de passagem que oferecem uma identidade para o jovem. O sujeito moderno não tem essas marcas pré-estabelecidas, toda sua identidade depende de seus movimentos próprios. Assim, talvez, estes jovens autores de atos infracionais podem viver a formula cartesiana com uma inovação: "sinto, logo existo". Será preciso construir uma identidade e garantir a sensação de vida através da atuação. No ato da infração o sujeito sente o pulsar de seu corpo 
confirmando, pois, a sua vida e existência. A filiação ao grupo e o sentimento de estar vivo, operando na realidade, pode ser garantindo pelo ato infracional.

Mas, porque estamos propondo uma inovação no preceito cartesiano? Porque, na verdade, o projeto moderno fracassa como possibilidade de contenção e minimização da condição humana de desamparo. Assim, surge a perspectiva pós-moderna ${ }^{2}$, que assume 0 profundo caos apresentado no início da modernidade e denuncia a impossibilidade da solução racional, criando assim verdadeiras revoluções da sensibilidade, que podem ser traduzidas pelo imenso individualismo e pelo aumento da busca de experiências sensoriais que desafiam limites como, por exemplo, nos esportes radicais. Mas acolher a fragmentação e a efemeridade pode produzir uma perda do sentido individual e coletivo, desnudar a condição de desamparo (HARVEY, 1992).

Se tudo é relativo e provisório, devo viver intensamente o meu agora, sem preocupar-me com o outro e o futuro. Nesse sentido, ocorre um crescente aumento de patologias como a depressão, a toxicomania, o transtorno do pânico e uma liquidez do laço social. O sujeito adota uma perspectiva narcisica e auto-centrada. Mas, como revela Birman o autocentramento do sujeito em seu eu, o fechamento nas exigências narcísicas, ocorrem sem as noções de interioridade e auto-reflexão, comuns ao início da modernidade. O autor anuncia que "os destinos do desejo assumem, pois, uma direção marcadamente exibicionista e autocentrada, na qual o horizonte intersubjetivo se encontra esvaziado" (BIRMAN, 1999, p. 24). Os encontros são esvaziados de densidade existencial, os vínculos são frouxos, e o sujeito tem baixa capacidade de simbolização. E, o sujeito vale pelo que parece ser; portanto, é necessário ter boa performance. Paradoxalmente, o sujeito é prisioneiro de si, mas a faceta exibicionista drena a energia, não em direção ao outro, e sim na busca fracassada da imagem total. Lasch e Debors, em suas leituras sobre a pós-modernidade ${ }^{2}$, produziam as idéias de Cultura do narcisismo e Sociedade da performance. Segundo Lasch, certos padrões característicos da cultura contemporânea revelam sua face narcisista, padrões como "temor intenso da velhice e da morte, o senso de tempo alterado, o fascínio pela celebridade, o medo da competição, o declínio do espírito lúdico" (LASCH, 1983, p. 57). A cultura narcisista opera um enfraquecimento do vínculo social, pois existe uma tendência a minimizar seu campo de investimento libidinal, reduzindo-o ao próprio ego, mas buscando produzir uma imagem performática. O que há de comum entre as leituras de Lasch e Debors é que o sujeito pós-moderno perde suas relações com o tempo e a história. Segundo Safra (2006), na atualidade, surgem psicopatologias decorrentes da ruptura do indivíduo 
com a sua história. O restabelecimento da memória é questão vital na recuperação das posições subjetivas. O citado autor apresenta-nos várias possibilidades clínicas de retecer a história do sujeito:

1. Memória representada: elementos que representam a história de uma pessoa, articulados pela suas angústias e desejos;

2. Memória inconsciente: aspectos que se revelam na situação transferencial desvelando o reprimido;

3. Memória do não acontecido: situações que são pressentidas no curso da vida e que assinalam as necessidades ontológicas;

4. Memória étnica: formas sensoriais que constituíram a fundação do self e que enraízam a pessoa em uma determinada etnia (SAFRA, 2006).

A vida pós-moderna, assim como suas mudanças culturais, promovem uma aceleração do tempo de giro na produção envolve acelerações paralelas na troca e no consumo e, por fim, uma desorientação espaçotemporal nos sujeitos. E, assim, criam mais possibilidades de ruptura do sujeito com sua história e tradição retirando uma força vital que pode proteger as pessoas de formas de adoecimento e promovem o laço social.

Giddens (1997) revela que a tradição é uma das possibilidades de conexão com o tempo e com o outro. Ela tem um conteúdo normativo ou moral que proporciona uma conexão entre passado e presente e a construção de uma identidade social. Segundo ele, as sociedades modernas tornaram-se destradicionalizadas e "as ameaças à integridade das tradições são ameaças à integridade do eu" (GIDDENS, 1997, p. 100). A tradição proporcionava uma âncora para aquela confiança básica tão fundamental para a continuidade da identidade e para a sustentação do vínculo social.

É nesse sentido que Bauman (2001) forja a expressão modernidade líquida, pois todos os vínculos se "derramam" e escoam sem manter uma estabilidade. Bauman (1998) revela que cada época produz o seu campo de exclusão e no caso da modernidade líquida este campo é habitado por aqueles que não podem consumir. Assim, perguntamos: Como os jovens, sujeitos de nossa reflexão, podem se relacionar com este campo de exclusão? Qual a relação entre esse campo e suas possibilidades de enlaçamento social? Mais especialmente, como se articulam com o desenvolvimento da criminalidade violenta? Quais são os efeitos da destradicionalização e do impacto da sociedade pósmoderna em seus processos de subjetivação? 


\section{O sujeito em questão: o jovem e a transição característica da adolescência}

Além da dimensão macro-estrutural do contexto pós-moderno, em termos gerais, e do contexto nacional, em específico, um terceiro elemento a estes se soma e agrega a nossos questionamentos outro viés de leitura. Trata-se da experiência da adolescência ${ }^{3}$ e das características específicas de sua lógica de funcionamento. Ainda que adolescência não seja um conceito psicanalítico, mas envolva, como estamos verificando, dimensões sociais, econômicas e culturais, entre outras, partiremos aqui da doutrina freudiana para circunscrever os principais elementos subjetivos nela envolvidos.

Freud (1905) utiliza o termo puberdade, descrevendo-o como um segundo tempo da sexualidade. O primeiro ocorre na infância e retrocede ou é detido na latência; e o segundo sobrevém com a puberdade e determina a configuração definitiva da vida sexual. Ele explica que, com a chegada da puberdade, introduzem-se as mudanças que levam a vida sexual infantil à sua configuração definitiva. A pulsão na infância era predominantemente auto-erótica e na puberdade encontra o objeto sexual. Surge um novo alvo sexual para a conjunção de todas as pulsões parciais: a zona genital.

Esclarece, portanto, que, com a chegada da puberdade, duas transformações são decisivas: a subordinação de todas as outras fontes de excitação sexual ao primado das zonas genitais e o processo do encontro do objeto. Freud acrescenta que a normalidade da vida sexual só é assegurada pela exata convergência das duas correntes dirigidas ao objeto sexual e à meta sexual: a de ternura e a sensual: "A primeira destas comporta em si o que resta da primitiva eflorescência infatil da sexualidade. É como a travessia de um túnel perfurado desde ambas as extremidades" (FREUD, 1905, p. 195).

Ele também destaca na adolescência o trabalho que o jovem deve fazer de separação de seus pais. Ele explica que na puberdade há o redespertar do Édipo, renovando os conflitos edipianos e as fantasias incestuosas.

Contemporaneamente à subjugação e ao repúdio dessas fantasias claramente incestuosas consuma-se uma das realizações psíquicas mais significativas, porém também mais dolorosas, do período da puberdade: o desligamento da autoridade dos pais, unicamente através do qual se cria a oposição, tão importante para o progresso da cultura, entre a nova e a velha gerações. (FREUD, 1905, p. 213) 
Em 1914, em Algumas reflexões sobre a psicologia do escolar, Freud faz algumas reflexões sobre a adolescência, marcando em especial, o desligamento que o jovem faz do pai e sua substituição pela figura do mestre. Freud explica que é nessa fase do desenvolvimento do jovem que sobrevém seu encontro com o mestre. Ele acrescenta que tudo o que distingue a nova geração, tanto o que é portador de esperança quanto o que choca, tem como condição esse desligamento do pai. Ou seja, a crise do pai faz nascer a nova geração.

Neste movimento, a função de interdição edípica, bem como a abertura à possibilidade do exercício do desejo ampliam-se para sua concretização no pacto social. Aqui temos, de saída uma questão fundamental em nossa análise. Quando o pai não comparece, de que maneira o sujeito realiza e potencializa sua figura? Quando o pacto social não funciona em suas regras mínimas de segurança e liberdade para uma criança e para um adolescente, como ele responderá à disfunção social? Temos aqui uma via de mão dupla entre os termos edípicos e sociais. E, se não se espera uma reciprocidade idealizada de seus termos, fato é que sua dissimetria radical também gerará, certamente, conseqüências no planos subjetivos e sócio-político.

Além do luto pelos pais infantis e desta passagem para o plano social, o adolescente realiza também um trabalho com o corpo em transformação. A construção especular do eu feita na infância é perturbada na adolescência. O corpo "púbere", em transformação, denuncia os pontos de fraqueza da "unidade especular" construída na infância. As perguntas sobre o ser, sobre o sexo, sobre o próprio desejo e o desejo do Outro simbólico, surgidas na infância e silenciadas na latência, são re-despertadas na adolescência. O Outro aqui é usado no sentido do campo simbólico ao qual o sujeito do inconsciente está remetido. E sua consistência imaginária é abalada nesta fase. O adolescente terá que fazer um intenso trabalho de construção imaginária da realidade, quando o corpo desponta como fundamental ao sujeito.

Na adolescência, a gestalt do corpo muda, assim como a percepção que o jovem passa a ter de si e do meio que o cerca. Segundo Haim (1971), citado por Alberti (1999, p. 135), o adolescente tem medo de seu corpo e não sabe dele se servir. Ele então reinveste a imagem especular que o fazia reconhecer-se no outro imaginário. Mas o seu corpo é agora o próprio objeto que lhe causa angústia, e sua imagem claudica. De acordo com Freud, a forma definitiva normal do corpo é assegurada pela fantasia, por meio da conjunção de duas correntes, a terna e a sensual, em direção ao objeto e ao fim sexual. 
Lacan (2003), por seu turno, vai apontar a adolescência como fornecedora do paradigma da impossibilidade do encontro simétrico e recíproco com o outro. $\mathrm{Na}$ puberdade, há o despertar para a discordância entre o sujeito - que surge como produto dividido do recalmento - e o mundo das pulsões. Nesse tempo da puberdade, essa dicotomia se faz presente de forma contundente e não permite mais o recurso, utilizado pela criança, de lançar mão do Outro parental para fazer frente a este desencontro entre o sujeito dividido e a pulsão (ALBERTI, 1999) . O Outro parental, já estruturado a partir da função paterna, apresenta-se falho, incapaz de responder à altura dessa exigência. Os ideais vacilam, e os adolescentes vão à procura de novos ideais.

É neste período também que o encontro com o outro sexo ganha corpo. É exatamente no momento em que o rapaz satisfaz aos ideais de sua virilidade e a moça se instala na identificação, momento de assunção do desejo, que o encontro fracassa. Há um mal-estar, um impasse na relação sexual. Os desencontros dos primeiros amores são paradigmáticos do impasse da relação sexual. De acordo com Lacan (2003), quando chega a hora do rapaz fazer amor com as moças, é preciso que sonhe com isso, antes disso se ocupar. Em Televisão (1993), retomando o vocabulário da época que qualifica o adolescente de jovem, Lacan observa que sua relação ao sexo é marcada por dois afetos modernos, o tédio e a morosidade:

Se falei de tédio, e até mesmo de morosidade a respeito da abordagem "divina" do amor, como desconhecer que esses dois afetos são denunciados - em falas e até mesmo em atos - em jovens que se entregam a relações sem repressão - o mais incrível sendo que os analistas, em quem eles encontram suas motivações, lhes respondem fazendo birra. Mesmo que as recordações da repressão familiar não fossem verdadeiras, seria preciso inventá-las, e não se deixa de fazê-lo. O mito é isso, a tentativa de dar forma épica ao que se opera da estrutura (LACAN, 1993, p. 55).

Diante de todo esse trabalho psíquico: passagem do pai à lei social na ampliação do pacto edípico ao pacto social, elaboração do luto dos pais infantis, ressignificação da relação com o corpo, encontro com o outro sexo, Barros (1996) define a adolescência como um tempo onde é dado ao sujeito uma oportunidade de despertar, embora nem sempre isto aconteça. O que desperta o sujeito é o real de um gozo ${ }^{4}$ que rompe os recursos simbólicos construídos para lidar com ele: 
A psicanálise nos alerta para a dificuldade do despertar. Quando dormimos e somos atingidos por algum estímulo que nos obrigaria a acordar, sonhamos para continuar dormindo. E, se durante o sonho algo irrompe e contraria seu trabalho de realização do desejo que mantém o sono, acordamos para continuar dormindo, embalados pela nossa realidade psíquica, que recobre com a fantasia o que provocaria o despertar. Nem sempre o encontro faltoso com o real que faz acordar, desperta. No entanto ele deixa a marca de um limite, que exigirá do sujeito uma resposta, mais cedo ou mais tarde (BARROS, 1996, p. 69).

Alberti (2004) considera que a própria adolescência é uma escolha do sujeito. Ele pode escolher atravessá-la ou não. Para a autora, a adolescência como escolha do sujeito, implica em pagar o preço do desligamento dos pais, assumir que só se pode contar com o Outro em nível simbólico. Mas isso só é possível quando o sujeito tem uma referência a um pai que pode relativizar, mediatizar e barrar o desejo da mãe, por um lado. E, por outro, do pai que consente e abre a possibilidade para o 'sim', para o desejo, ao se apresentar, ele próprio, como desejante. Contingente, porém determinante, a passagem pela adolescência é decisiva na conclusão da vida infantil e na entrada na vida adulta.

\section{Juventude, Contemporaneidade e Criminalidade Violenta: tecendo a trama}

O adolescente na contemporaneidade, entretanto, sofre um empuxo ao discurso capitalista. O discurso capitalista visa a produção constante de objetos, que devem ser rapidamente consumidos, obedecendo às leis do mercado. O objeto de consumo passa a ocupar um lugar de comando na estrutura do discurso, fazendo desaparecer as expressões individuais e determinando no sujeito certa suspensão de sua divisão subjetiva. Há uma mudança na posição do saber, que passa a ser tomado como valor de mercado, subvertendo o desejo. O sujeito é estimulado a buscar sua completude imaginária no objeto, tamponando sua castração. No entanto, o objeto, uma vez adquirido, perde seu valor e é descartado, numa produção vertiginosa. O sujeito é comandado pela presença do objeto, mas dentro das leis de mercado. Assim, o sujeito adolescente, no momento em que é confrontado com a falta estrutural, recorre aos objetos de consumo na tentativa de tamponar sua divisão subjetiva, escamoteando sua castração.

Segundo Leal (1996), vivemos a perda da liberdade em função do imperialismo dos objetos. Assim, o jovem fica submetido à avalanche de objetos, gadgets, produzidos pela ciência e pela tecnologia. 
totalitarismo dos objetos aponta que tudo está ao alcance, que não há nenhuma barreira ao gozo. O apelo à auto-imagem, à auto-estima, à auto-ajuda, ao culto narcísico do corpo, se expande a todos os espaços e países. O discurso capitalista mostra a possibilidade de nada faltar, corroborado pela promessa tecnológica. Como vimos, segundo Bauman (2004, p. 21-22), a cultura consumista favore o produto pronto para o uso imediato, o prazer e a satisfação instantâneos, resultados rápidos sem esforços prolongados, receitas já testadas e garantias de seguro total. Mercadorias que fascinam e seduzem prometem desejo sem ansiedade e sem esforço.

A abundância de imagens na contemporaneidade revela uma perda, que é simbólica. Há uma falência dos ideais norteadores da identificação do sujeito, que constituem o lastro simbólico das imagens. Esse lastro, no caso dos jovens que analisamos, já é precário dada as condições em que, muitas das vezes, as crianças são criadas nos aglomerados. Com uma estrutura familiar matrilinear e com a ausência de uma figura masculina de referência, esses meninos carecem até mesmo da presença física das mães, ocupadas que estão com a manutenção financeira da casa (AMAS, 1995). De um lado essa carência estrutural, de outro uma super oferta de imagens e objetos de fácil acesso. No intervalo, o sujeito que tenta fazer consistir seu desejo. As saídas não são fáceis.

Para Lacan, se há uma perda simbólica relacionada à falência da função paterna, o simbólico falha em sua função de recobrir o real, o indizível, aquilo que a palavra nunca alcança. Como conseqüência pode, por exemplo, provocar a sua irrupção sob a forma de violência, delinqüência e drogadicção. Por outro lado, exacerba-se o imaginário, trazendo como conseqüência a alienação a uma imagem fascinante e sedutora, como, em outro exemplo, a do traficante poderoso e influente.

A relação com o Pai, enquanto função paterna, desdobra-se em dois aspectos: o Nome- do-Pai, como universal da lei, e o desejo, como momento da singularidade do sujeito. A verdadeira função do pai será, então, exercida entre os dois lados opostos de suas conseqüências clínicas possíveis. Quando se pensa, portanto, em "carência" do Pai, ela não diz respeito propriamente a uma falha do simbólico, a um enfraquecimento da lei (no sentido do relaxamento ou até mesmo do desaparecimento da autoridade exercida sobre o filho), mas a uma demissão do pai real, relativamente ao desejo da mãe (ZENONI, 2007). Quando a mãe não está privada do objeto de seu desejo ou, em outras palavras, quando ela parece tê-lo, sem necessidade de se dirigir ao homem, quando seu desejo não está dividido entre o filho e o homem (MILLER, 2003, p. 7), o filho corre sério risco de ficar preso no desejo de 
"ser" este objeto do desejo, no lugar de uma preferência-identificação por "aquele que tem", na condição de "I deal do eu".

Do lado oposto, no outro vértice dessas consequências clínicas, a derrota da verdadeira função do pai acontece, paradoxalmente, na própria medida em que se realiza a identificação do sujeito genitor ao Nome-do-Pai como universal do Pai, como vetor do absoluto e do abstrato do simbólico (MILLER, 2003, p.10). Confundir-se com o universal, identificar-se à Lei, com a exclusão de qualquer manifestação da particularidade do desejo, é o risco da falsa paternidade. A partir daí, tanto a confiança na palavra quanto o reconhecimento da própria noção de Lei ficarão fortemente comprometidos, uma vez que o sujeito preso a uma atitude de desconfiança passará a ler, em tudo o que disser respeito ao Outro, os sinais da traição ou da impostura.

Neste vértice, podemos identificar a desconfiança do jovem em relação às figuras sociais da lei, como a polícia e a Justiça, por um lado. E, por outro, podemos ler o apelo a uma lei supostamente protetora, que o resguardaria do capricho do outro. Assim, verificamos a entrada do jovem num código de regras rígidas do tráfico e das gangues, por exemplo. Longe, porém, de protegerem o sujeito, as regras rígidas desses coletivos parecem repetir a mesma estrutura da lei despótica e universal, outrora encarnada pelo Pai, que retira a condição para o ser desejante. Lei que passa, então, a ser encarnada pelo chefe do poder local. Presa de uma liberdade imaginária, o jovem aliena-se nas exigências do grupo, adormecido.

Aqui vemos a conjunção da incidência da figura paterna falhar nas duas possibilidades de inscrição da Lei acima discutidas. O pai real, demitido como desejante em relação à figura materna, deixa o filho no risco de desejar "ser" o que falta ao outro (inicialmente materno). Trata-se de uma possível conseqüência subjetiva da demissão paterna factual com que nos deparamos nas famílias matrilineares contemporâneas. A essa modalidade de falha da transmissão de um desejo não anônimo pelo pai soma-se a encarnação do pai como universal da Lei pelo traficante. Nessas situações, o traficante encarna a Lei, ao contrário de a veicular pela interdição a qual estaria, ele próprio, também submetido. Assim, parece-nos, o jovem, na busca de reparar o ponto em que seu desejo se aliena na posição de "ser" o que falta ao outro, acaba por se submeter crendo se proteger - junto à lei tirânica e não-dialetizável do tráfico.

Além disso, atualmente assistimos à multiplicação contingente dos ideais, com efeitos de fragmentação no nível do eu, que Soler (2001) chamou de processo de esquizofrenização do sujeito moderno. Trata-se de todos os processos de esquize que se inscrevem no real ou no simbólico e que têm por efeito atacar a coesão dos laços sociais. O 
esquizofrênico, psicótico, por se constituir fora do campo do desejo do Outro, não se vê no espelho, através desse ponto simbólico situado fora da imagem, suporte da identificação simbólica ao ideal do eu. Assim, falta ao sujeito esquizofrênico uma identificação organizadora, permanecendo então uma imago do corpo despedaçado. O corpo para ele é experimentado como não integrado, cujas partes não fazem um todo. O excesso de imagens na contemporaneidade, portanto, contribui para uma espécie de 'esquizofrenização' do sujeito moderno (não psicótico), tendo efeitos de dispersão na subjetividade e penalizando o eu.

Isso não significa que o sujeito moderno é um esquizofrênico, mas que ele vive uma dispersão dos ideais que modifica a sua relação com seu corpo. Há uma inconstância da imagem do próprio corpo. Há o desaparecimento de uma imagem do corpo que se mantenha, que não seja rapidamente destituída. Os adolescentes, nessa fase de reatualização e reorganização da imagem corporal, sofrem seus efeitos de forma cada vez mais avassaladora.

Jameson, também utilizando a descrição de Lacan da esquizofrenia como desordem lingüística, como uma perda simbólica, ou seja, como uma ruptura na cadeia significativa de sentido, concorda com a posição de Soler, vendo um certo efeito "esquizofrênico" na pós-modernidade. Segundo o autor, se a identidade pessoal é forjada por meio de

(...) certa unificação temporal do passado e do futuro, com o presente que tenho diante de mim, e se as frases seguem a mesma trajetória, a incapacidade de unir passado, presente e futuro na frase assinala uma incapacidade semelhante de unificar o passado, o presente e o futuro da nossa própria vida psíquica (J AMESON apud Harvey, 1992, p. 56).

O efeito desse colapso da cadeia significativa é reduzir "uma série de presentes puros e não relacionados no tempo" (J AMESON apud HARVEY, 1992, p. 57), como vimos. O sujeito, nessa cultura narcísica, é levado a crer num eu privado, que o remete à posição de eu ideal, como unidade e completude. Essa cultura se apóia no projeto individualista da modernidade, que valoriza o indivíduo em detrimento do sujeito. Esse individualismo remete 0 sujeito ao desconhecimento de sua determinação simbólica, numa crença de autonomia. Nesse ideal individualista de autonomia, o sujeito é levado a produzir sua própria história, tendo que romper com sua tradição, com sua história, num "aqui e agora" eternos.

Essa autonomia, porém, é ilusória, já que, por um lado, sua alienação ao Outro é constitutiva e, por outro lado, na tentativa de manter o lugar 
valorizado pela ideologia, vive a servidão de um imaginário de massa, que ganha coloração local, adquirindo as mesmas modalidades de funcionamento e de expressão discursivas transmitidas pela comunicação global. Ou seja, nessa ilusão de autonomia, ele nega sua alienação estrutural e, ao mesmo tempo, se submete a uma alienação à imagem como atualização dos modelos locais e/ou de massa, como esterótipos estéticos e estilos de vida ditados pela moda.

Diante da precariedade de significação social da cultura contemporânea, - sujeito tenta encontrar novas formas de estabelecer laço social, buscando alguma amarra coletiva. A entrada numa gangue ou num circuito criminoso oferece, diante dessa carência simbólica, uma promessa de sentido social, como uma ilusão comunitária. O sujeito fica submetido aos ideais narcísicos impostos pela cultura local. Na verdade, o poder desses coletivos existe porque o sujeito atribui a eles esse poder, em função de sua carência simbólica, ou seja, diante de sua precária consistência subjetiva.

Por outro lado, sua onipotência estrutural narcísica é exacerbada na cultura local, que o mantém numa eterna ilusão de alcançar sua plenitude de satisfação, buscando tamponar sua falta constitutiva. O sujeito, portanto, é afetado na sua posição subjetiva pelas práticas de sua cultura e do seu tempo, que vão aparecer sob a configuração de diversos sintomas sociais (LIMA, 2003, p. 70).

\section{Para finalizar o texto sem exaurir as questões}

Podemos pensar os diferentes modos de subjetivação como a relação que cada sujeito estabelece com seu campo discursivo, corporal, com seu espaço de prazer e de sofrimento. Trata-se de pensar como o sujeito habita seu espaço discursivo, seu corpo e a relação com a alteridade. É do ponto em que nos reconhecemos no Outro que extraímos a essência de nosso ser e nos posicionamos na vida. Nessa perspectiva, podemos pensar a articulação do território subjetivo com o campo social, ou seja, o laço social. A questão pode também ganhar outra dimensão: como o sujeito se faz habitar, e não apenas como sujeito se faz habitante.

O lugar habitado pelo sujeito (do inconsciente) implica na extração lógica de um lugar no campo do Outro, território simbólico que orienta uma existência. É exatamente do ponto a partir do qual nos perdemos no Outro para nascer como sujeitos - ponto que jamais se explica - que nossa existência subjetiva se constitui. É nele que localizamos a perda que /tentamos, com nossa existência, apreender e justificar. É dele que construímos nossa versão de eu. 
E será ele, também, que precisaremos desconstruir para habitar a vida de outra forma, de uma posição menos alienada e mais desejante, como o despertar da adolescência permite realizarmos. É este o ponto de torção entre o externo e o interno, que podemos pensar como os dois lados de uma faixa retorcida sobre si mesma. Nela o externo se torna interno e vice-versa. É aí que a dor do ser se escreve, pois, mesmo sem o saber conscientemente, o sujeito sofre suas conseqüências no corpo, na palavra, na vida. É nesta torção, ao tentar dar nome ao que é maior que a palavra e que a representação, que o sujeito se perde e sacrifica sua existência. Tentando obstruir o ponto de abertura ao desejo que essa impossibilidade de significação cria.

Aqui vemos a realidade factual com seus determinantes objetivos (econômicos, sócio-culturais, demográficos, arquitetônicos, entre outros) articular-se à dimensão subjetiva, igualmente determinante, na forma de ocupação da vida pública por esses jovens. Longe de apoiarmo-nos em determinantes exclusivistas, verificamos uma complexidade de fatores articularem-se na escolha pela criminalidade, conduzindo-nos a interrogarmo-nos pela conjuntura estrutural e também contingente dessa conjunção, mais que por sua causalidade. E longe de defendermos um modelo psicologizante de leitura, buscamos articular a dimensão subjetiva como mais um elemento de análise junto à realidade concreta em que esses jovens se encontram.

Nesse sentido, a realidade psíquica - enquanto aquilo que determina o modo de relação do sujeito com o mundo - é tomada como condição de possibilidade de sua interpretação subjetiva se inscrever na realidade externa. A partir deste registro, o sujeito se liga a seu espaço geográfico local e a seu tempo histórico mundial. É neste ponto que verificamos um encontro entre o local e o mundial e entre o singular e o universal, favorecendo a articulação de elementos a princípio díspares como sujeito e cidade, libido e laço social, inconsciente e capital, gozo e civilização (ou barbárie). Foi dele que partimos e a ele que retornamos para pensar a relação entre juventude e criminalidade violenta. E será com ele que concluiremos nossas embrionárias reflexões, oferecendo-o como novo ponto de partida para outros diálogos e novas vozes animadas pela mesma questão.

\section{Referências Bibliográficas}

ALBERTI, S. Esse sujeito adolescente. Rio de Janeiro: Rios Ambiciosos, 1999.

. O adolescente e o Outro. Rio de Janeiro: Jorge Zahar, 2004. 
AMAS-PREFEITURA DE BELO HORIZONTE. Famílias de crianças e adolescentes: diversidade e movimento. Belo Horizonte: AMAS, 1995. ASSIS, S. G.; SOUZA, E. R. Criando Caim e Abel: pensando a prevenção da infração juvenil. Ciência e saúde coletiva, Rio de Janeiro, v. 4, n. 1, 1999. Disponível em: <http://www.scielo.br/scielo.php?script=sci_arttext\&pid=S1413$81231999000100011 \&$ Ing =pt\&nrm=iso >. Acesso em: 12 Mar. 2008. BARROS, M. R. C. R. "Adolescência: quê despertar?" In: RIBEIRO, H. C. e POLLO, V. (Orgs). Adolescência: o despertar. Kalimeros/Escola Brasileira de Psicanálise. Rio de Janeiro: Contra Capa, 1996, p. 69-80. BAUMAN, Z. O mal-estar da pós-modernidade. Rio de Janeiro: Jorge Zahar, 1998.

Modernidade líquida. Rio de Janeiro: J orge Zahar, 2001.

Amor líquido: sobre a fragilidade dos laços humanos. Rio de Janeiro: J orge Zahar, 2004.

BEATO F. C. C. Determinantes da criminalidade em Minas Gerais. Revista Brasileira de Ciências Sociais. São Paulo, v.13, n. 37, Jun. 1998, p. 33-54.

BIRMAN, J. Mal-estar na atualidade - A psicanálise e as novas formas de subjetivação. Rio de Janeiro: Civilização Brasileira, 1999.

CHESNAIS, J. C. A violência no Brasil. Causas e recomendações políticas para sua prevenção. Ciência e Saúde Coletiva, ano 4, no. 1, 1999, p. 53-69.

DIÓGENES, G. Cartografias da cultura e da violência: gangues, galera e o movimento hip hop. São Paulo: Anna Blume, 1998.

DUMONT, L. O individualismo: uma perspectiva antropológica da ideologia moderna. Rio de Janeiro: Rocco, 1985.

FREUD, S. "Algumas reflexões sobre a psicologia do escolar [1914]". In: Edição Standard Brasileira das Obras Psicológicas Completas de Sigmund Freud. Rio de Janeiro: Imago, 1976, v. XIII, p. 281-288.

"O estranho [1919]". In: Edição Standard Brasileira das

Obras Psicológicas Completas de Sigmund Freud. Rio de Janeiro: Imago, 1976, v. XVII, p. 273-318.

"Três ensaios sobre a teoria da sexualidade [1905] (Ensaio III)".

In: Edição Standard Brasileira das Obras Psicológicas Completas de Sigmund Freud. Rio de J aneiro: Imago, 1976, v. VII, p. 195-230.

GIDDENS, A. A vida em uma sociedade pós-tradicional. In: GIDDENS, A.; BECK, U.; LAH, S. Modernização reflexiva. São Paulo: Editora da Universidade Estadual Paulista, 1997, p. 73-133.

HARVEY, D. Condição pós-moderna. São Paulo: Loyola, 1989 e 1992. 
JAMESON, F. O pós-modernismo e a sociedade de consumo. In: Pósmodernismo: a lógica do capitalismo tardio. São Paulo: Ed. Ática, 1997.

JUNQUEIRA, M. R.; JACOBY, M. O olhar dos adolescentes em conflito com a lei sobre o contexto social. Revista Virtual Textos \& Contextos, ano 5, no 6, dez. 2006, p. 02-18. LACAN, J. Prefácio a 'O despertar da primavera' (1974). In:

Outros Escritos. Rio de Janeiro: Jorge Zahar, 2003, p. $5 \overline{5} \overline{7}-\overline{5} \overline{5} \overline{9}$. (Campo Freudiano no Brasil)

no Brasil).

. Televisão. Rio de Janeiro: Jorge Zahar,1993. (Campo Freudiano

LASCH, C. A cultura do narcisismo (cap. II: A personalidade narcisista de nossos dias). Rio de Janeiro: Imago, 1983, p.55-78.

LEAL, C. E. "Adoleiscente: contra a ordem e o progresso?" In: RIBEIRO, H. C. e POLLO, V. (Orgs). Adolescência: o despertar. Kalimeros/Escola Brasileira de Psicanálise. Rio de Janeiro: Contra Capa, 1996, p. 69-76.

LIMA, N. L. Fascínio e Alienação no ciberespaço. Belo Horizonte: FAE/UFMG, 2003.

MILLER, J. A. L'enfant et l'objet. La petite girafe. Revue du Champ freudien. Paris, n. 18, v. 7, Octobre 2003.

MVBILL; ATHAYDE, C. e SOARES, L. F. Cabeça de Porco. Florianópolis: Objetiva, 2005.

NASCIMENTO, L. F. Z. Violência e criminalidade em vilas e favelas dos grandes centros urbanos: um estudo de caso da Pedreira Prado Lopes. Dissertação de Mestrado em Ciências Sociais, $(230$ f. $)$, Faculdade de Filosofia e Ciências Humanas, Universidade federal de Minas Gerais, Belo Horizonte, 2004.

NUNES, M. Idiomas culturais como estratégias populares para enfrentar a violência urbana. Ciência e saúde coletiva, Rio de Janeiro, v. 10, n. 2, 2005. Disponível em:

<http://www.scielo.br/scielo.php?script=sci_arttext\&pid=S1413-

$81232005000200019 \&$ Ing $=$ pt\&nrm=iso>. Acesso em: 12 Mar. 2008. SAFRA, G. Memória e Subjetivação. Memorandum, 2, 21-30. 2002. Disponível em:

<http://www.fafich. ufmg.br/ memorandum/artigos02/safra02.htm>. Acesso em: 25 Ago. 2006.

SANT'ANNA, A; AERTS, D; LOPES, M. J. Homicídios entre adolescentes no Sul do Brasil: situações de vulnerabilidade segundo seus familiares.

Cadernos de Saúde Pública, Rio de Janeiro, v. 21, n. 1, 2005. Disponível em: <http://www.scielo.br/scielo.php?script= sci_arttext\&pid=S0102-311X2005000100014 \&lng=pt\&nrm=iso>. Acesso em: 12 Mar. 2008. 
SILVA, L. A. M. Sociabilidade violenta: por uma interpretação da criminalidade contemporânea no Brasil urbano. Sociedade e estado, Brasília, v. 19, n. 1, 2004. Disponível em: <http://www.scielo.br/scielo. php?script=sci_arttext\&pid=S010269922004000100004

$\&$ lng $=p t \& n r m=i s o>$. Acesso em: 12 Mar. 2008. SOLER, C. A esquizofrenia. In: QUINET, A (org.). Psicanálise e psiquiatria: controvérsias e divergências. Rio de Janeiro: Rios Ambiciosos, 2001, p. 237-248. . Um mais de melancolia. In: QUINET, A (org.). A dor de existir

e suas formas clínicas: tristeza, depressão e melancolia. Rio de Janeiro: Kalimeros/Contra Capa, 1997, p. 165-187.

ZALUAR, A. A máquina e a revolta. São Paulo: Brasiliense, 1985.

- Democratização inacabada: fracasso da segurança pública.

Estudos Avançados, São Paulo, v. 21, n. 61, 2007. Disponível em: <http://www.scielo.br/ scielo.php?script=sci_art

text\&pid=S0103-40142007000300003\&Ing $=$ pt\&nrm=iso>. Acesso em: 12 Mar. 2008.

ZENONI, A. Versões do pai na psicanálise lacaniana: o percurso do ensinamento de lacan sobre a questão do Pai. Revista em Psicologia. Belo Horizonte, v. 13, n 01, junho de 2007, p. 15-26.

\section{Endereço para correspondência}

Andréa Máris Campos Guerra

Programa de Pós-graduação em Psicologia, Av. Itaú, no 525, Bairro Dom Cabral CEP 30535-012, Belo Horizonte-MG, Brasil

Endereço eletrônico: ppgpsi@pucminas.br

Jacqueline de Oliveira Moreira

Programa de Pós-graduação em Psicologia, Av. Itaú, no 525, Bairro Dom Cabral CEP 30535-012, Belo Horizonte-MG, Brasil

Endereço eletrônico: ppgpsi@pucminas.br

Nádia Laguárdia de Lima

Programa de Pós-graduação em Psicologia, Av. Itaú, no 525, Bairro Dom Cabral CEP 30535-012, Belo Horizonte-MG, Brasil

Endereço eletrônico: ppgpsi@pucminas.br

Programa de Pós-graduação em Psicologia, Av. Itaú, no 525, Bairro Dom Cabral CEP 30535-012, Belo Horizonte-MG, Brasil

Endereço eletrônico: ppgpsi@pucminas.br

Camila Alves Noberto Soares

Programa de Pós-graduação em Psicologia, Av. Itaú, no 525, Bairro Dom Cabral CEP 30535-012, Belo Horizonte-MG, Brasil

Endereço eletrônico: ppgpsi@pucminas.br

Liliany Mara Silva Carvalho

Programa de Pós-graduação em Psicologia, Av. Itaú, no 525, Bairro Dom Cabral CEP 30535-012, Belo Horizonte-MG, Brasil 
Endereço eletrônico: ppgpsi@pucminas.br

Naiane de Andrade Nascimento Pechir

Programa de Pós-graduação em Psicologia, Av. Itaú, no 525, Bairro Dom Cabral CEP 30535-012, Belo Horizonte-MG, Brasil

Endereço eletrônico: ppgpsi@pucminas.br

Recebido em: 02/11/2008

Aceito para publicação em: 23/11/2009

Acompanhamento do processo editorial: Anna Paula Uziel

\section{Notas}

* Doutora em Teoria Psicanalítica (UFRJ com estágio de Estudos Aprofundados em Rennes II), mestre em Psicologia Social (UFMG) e psicanalista.

** Doutora em Psicologia Clinica - PUC/SP, Mestre em Filosofia - UFMG, Psicóloga clinica.

*** Coordenadora do curso de especialização em “Clínica Psicanalítica nas Instituições de Saúde da PUC-MG", psicanalista, doutoranda em Educação (UFMG) e mestre em Educação (UFMG).

****Aluna e voluntária na pesquisa "A construção do laço social de jovens moradores de territórios com alto índice de criminalidade violenta", financiada pelo FIP-PUC e CNPq.

*****Aluna e voluntária na pesquisa "A construção do laço social de jovens moradores de territórios com alto índice de criminalidade violenta", financiada pelo FIP-PUC e CNPq.

$* * * * * *$ Aluna e bolsista na pesquisa "A construção do laço social de jovens moradores de territórios com alto índice de criminalidade violenta", financiada pelo FIP-PUC e CNPq.

$* * * * * * *$ Aluna e bolsista na pesquisa "A construção do laço social de jovens moradores de territórios com alto índice de criminalidade violenta", financiada pelo FIP-PUC e CNPq.

1 Consulta realizada em Setembro de 2008 no seguinte endereço eletrônico: http://www3.fgv.br/ibrecps/RET3/Midia/jc888. pdf.

${ }^{2}$ Não existe consenso sobre a utilização da expressão "pós-modernidade", mas, nessa pesquisa não pretendemos investigar as diferentes nomeações para nossa contemporaneidade.

${ }^{3}$ A adolescência é considerada pela Organização Mundial de Saúde como a faixa etária compreendida entre 10 e 19 anos.

${ }^{4}$ O gozo é uma espécie de sofrimento prazeiroso. Enquanto o desejo potencializa a relação com a vida, o gozo amarra a relação com a pulsão de morte, sendo-lhe correlata. É o ponto de retorno ao qual o sujeito insistentemente volta, para tentar assimilá-lo simbolicamente, posto que ele é um excedente sem tradução. 